\title{
33. A STRUCTURAL ANALYSIS OF CORES FROM THE LEG 67 TRANSECT ACROSS THE MIDDLE AMERICA TRENCH-OFFSHORE GUATEMALA ${ }^{1}$
}

\author{
Carlos A. Dengo, Department of Geology and Center for Tectonophysics, \\ Texas A\&M University, College Station, Texas
}

\begin{abstract}
Deformation features within the cores are studied with a view towards elucidating the structure of the Middle America Trench along the transect drilled during Leg 67. Where possible, inferences are made as to the physical environment of deformation.

Extensional tectonics prevails in the area of the seaward slope and trench. Fracturing and one well-preserved normal fault are found mostly within the lower Miocene chalks, at the base of the sedimentary section. These chalks have high porosities $(40 \%-60 \%)$ and water content $(30 \%-190 \%$, based on $\%$ dry wt.). Experimental triaxial compression tests conducted on both dry and water-saturated samples of chalk from Holes 495 and 499B show that only in the saturated samples is more brittle behavior observed. Brittle failure of the chalks is greatly facilitated by pore fluid pressures that lead to low effective pressures. Additional embrittlement (weakening) can take place as a result of the imposed extensional stress resulting from bending of a subducting elastic oceanic plate. The chalks exhibit, in a landward direction, an increase in density and mechanical strength and a decrease in water content. These changes are attributed to mechanical compaction that may have resulted from tectonic horizontal compression.

The structure of the landward slope is not well understood because the slope sites had to be abandoned due to the presence of gas hydrate. The relationship of the chaotic, brittle deformation (observed in the cores from Hole 494A) at the base of the landward slope to tectonic processes remains unclear. The deformation observed on the slope sites (Holes 496 and 497 ) is mostly fracturing and near-vertical sigmoidal veinlets. These are interpreted as being the result of gas/fluid overpressurization due to the decomposition of the gas hydrate, and not due to tectonic loading of accreted sediments.

Aside from four small displacement (less than $1 \mathrm{~cm}$ ) reverse faults observed in the lower Miocene chalks (which may be the product of soft-sediment deformation), there is a noticeable absence of structures reflecting a dominance of horizontal (tectonic) compression along the transect drilled. The absence of such features, the lack of continuity of sediment types across the trench-landward slope, and the normal stratigraphic sequence in Hole 494A do not support any known accretionary model.
\end{abstract}

\section{INTRODUCTION}

One of the primary objectives of Leg 67 was to determine how oceanic sediments are accreted to the continental margin at the Middle America Trench, off the coast of Guatemala. Previous studies, particularly those of Seely et al. (1974) and Seely (1979), indicate that the sediments transported into the trench are not subducted. Instead, these are accreted to the continental margin in the form of imbricate, landward dipping, underthrust slices. Multichannel seismic reflection studies (Ladd et al., 1978; Ibrahim et al., 1979) do not show the ordered arrangement of the thrust slices as does the model of Seely and his co-workers, but show only the traces of two landward-dipping reflectors.

The results obtained from Leg 67 are not sufficiently conclusive either to confirm the thrust-wedge model of Seely et al. (1974) or to propose a definitive alternate structural model. Considering the volume of sediment input to the trench over time and of that which is presently accommodated on the slope, substantial amounts of sediment must have been either subducted or eroded (von Huene, Aubouin, et al., 1980). In order to consider

\footnotetext{
${ }^{1}$ Aubouin, J., von Huene, R., et al., Init. Repts DSDP, 67: Washington (U.S. Govt. Printing Office).
}

all possible alternatives, the Shipboard Party agreed to propose three schemes, which involve large-scale slumping, subduction without accretion, and tectonic erosion of a pre-Miocene accretionary complex (von Huene, Aubouin, et al., 1980).

On the basis of relative plate motion studies, the Middle America Trench is known to be a convergent plate margin (Minster and Jordan, 1978). Studies of earthquake focal mechanisms indicate that there is compressional tectonism at this plate boundary (Molnar and Sykes, 1969). Other evidence in favor of plate convergence includes calc-alkaline volcanism landward of the trench and seismic reflections showing that the oceanic crust is thrust under the continental slope (Ladd et al., 1978). Yet both the seismic records and the cores recovered on Leg 67 show a lack of structures that would support a model of compressional tectonics.

The seismic data indicate that seaward of the trench extensional tectonics is prevalent. The seaward slope is broken by normal faults, resulting in a "conveyor belt" of grabenlike structures being carried into the trench. These structures have been shown to be a common feature of subduction. Hilde and Sharman (1978) have suggested that where grabens within the subducting plate are well developed, sediment subduction rather than accretion is likely to dominate. Structures within the trench proper are obscured by diffractions, so that any inter- 
pretation of the seismic reflection profiles is uncertain. Landward of the trench, diffractions also obscure the structure, and only two landward-dipping reflectors could be discerned (Ladd et al., 1978; Ibrahim et al., 1979). On the landward slope the seismic data indicate normal faulting and/or large slump blocks. Studies of other active convergent plate margins nevertheless indicate that in some cases the trench floor and lower landward slope are undergoing tectonic compression (Carson, 1977; Moore and Karig, 1976; Seely, 1979; Kulm and Fowler, 1974; von Huene et al., 1978; Kieckhefer et al., 1980).

The objective of this paper is to attempt, on the basis of structures observed within the Leg 67 cores, to clarify the actual character of the deformation in the Middle America Trench along the Guatemala transect. These structures are studied with a view towards characterizing the deformation and inferring the deformation environment. Suggestions about the large-scale tectonic framework derived from structures observed within the cores will be somewhat speculative, because (1) the percentage of unconsolidated sediments is large, (2) core recovery at key sites is poor, (3) marker horizons (e.g., bedding planes) are too few, and (4) drilling-induced deformation is severe in many cases and has obliterated more subtle structures.

In the first section of this paper the structural features within the cores are described (mostly from Holes $495,500,494 \mathrm{~A}, 496$, and 497). This is followed by a section on the results obtained from triaxial compression experiments. These experiments were done to determine mechanical strength properties and to establish, if possible, a correlation between the ductility trends predicted from the experiments and the features observed in the cores. The possible relationship between the occurrence of gas hydrate and deformation in the slope sediments is also discussed. Even though the relation between gas hydrate and deformation seems unsubstantiated, I believe the discussion is merited in view of the increasing recognition that gas hydrates are important constituents of deep-sea sediments.

\section{OBSERVATIONAL RESULTS}

The cores utilized for petrofabric analyses are listed in Table 1 along with some physical properties. The following descriptions are mostly macroscopic and are done in a seaward to landward order and not in the order of drilling. These are not meant to be exhaustive of all the deformation observed, but will serve to establish the types of deformational features present. The location of each hole discussed is given in Figure 1.

As stated in the introduction, it is difficult to distinguish between drilling- and tectonic-induced deformation. In order to filter out the drilling effects, criteria were developed and agreed upon by the Shipboard Party. These criteria are listed in the Appendix.

\section{Data}

\section{Hole 495, Cocos Plate}

Deformation features in Hole 495 are confined mainly to the upper Miocene siliceous muds (Core 17) and the
Table 1. Summary of physical property data on cores used for petrofabric analyses.

\begin{tabular}{|c|c|c|c|}
\hline $\begin{array}{l}\text { Hole, Core, Section } \\
\text { (sub-bottom depth } \\
\text { in } \mathrm{m} \text { ) }\end{array}$ & $\begin{array}{l}\text { Average } \\
\text { GRAPE } \\
\text { Density } \\
\left(\mathrm{g} / \mathrm{cm}^{3}\right)\end{array}$ & $\begin{array}{c}\text { Porosity } \\
(\%)\end{array}$ & $\begin{array}{c}\text { Water } \\
\text { Content } \\
\text { ( } \% \text { dry wt.) }\end{array}$ \\
\hline \multicolumn{4}{|l|}{ Hole 495} \\
\hline $\begin{array}{l}17-1 \\
(152-153.5) \\
17-6 \\
(159.5-161) \\
30-1 \\
(275.5-277)\end{array}$ & $\begin{array}{l}1.30 \\
1.60\end{array}$ & $\begin{array}{l}- \\
- \\
-\end{array}$ & $\begin{array}{l}190 \\
190 \\
-\end{array}$ \\
\hline \multicolumn{4}{|l|}{ Hole 500} \\
\hline $\begin{array}{l}13-2 \\
(110.5-112) \\
13-3 \\
(112-113.5) \\
14-1 \\
(118.5-120)\end{array}$ & $\begin{array}{l}1.55 \\
1.55 \\
1.75\end{array}$ & $\begin{array}{l}- \\
- \\
-\end{array}$ & $\begin{array}{l}49 \\
49 \\
45\end{array}$ \\
\hline \multicolumn{4}{|l|}{ Hole 494A } \\
\hline $\begin{array}{l}17-1 \\
(189.5-191) \\
17-2 \\
(191-192) \\
22-2 \\
(238.5-240) \\
27-1 \\
(284.5-286)\end{array}$ & $\begin{array}{l}1.75 \\
1.75 \\
1.80 \\
1.95\end{array}$ & $\begin{array}{l}55 \\
55\end{array}$ & $\begin{array}{l}30 \\
34\end{array}$ \\
\hline $\begin{array}{l}\text { Hole } 496 \\
\qquad \begin{array}{l}36-7 \\
(339.5-340)\end{array}\end{array}$ & 1.55 & - & 40 \\
\hline \multicolumn{4}{|l|}{ Hole 497} \\
\hline $\begin{array}{l}25-1 \\
(225.5-227) \\
29-3 \\
(266-268)\end{array}$ & $\begin{array}{l}1.54 \\
1.56\end{array}$ & - & $\begin{array}{l}75 \\
76\end{array}$ \\
\hline
\end{tabular}

Note: - indicates no data available.

lower Miocene nannofossil-foraminiferal chalks (Core 30 ). Bedding markers could not be readily recognized in either core. The siliceous muds (Sections 495-17-1 and 495-17-6; Fig. 2A B, respectively) are mostly bioturbated. Remolding due to drilling is visible near the core liner edges, but well-preserved burrows (interval 101-105 cm and $112-116 \mathrm{~cm}$; Fig. $2 \mathrm{~A}$ ) suggest that overall drilling effects are minimal. Core 17, Section 6 (Fig. 2B) also has core liner effects. Two reverse faults cross the undisturbed part of the core. These have displacements less than $1 \mathrm{~cm}$ and an orientation of about $35^{\circ}$ to the core axis. It is not clear if these are the result of tectonic loading or of soft-sediment deformation.

A significant change occurs at Core 30 (the contact between the radiolarian and nannofossil oozes above with the foraminiferal-nannofossil chalks below). Section 495-30-1 (Fig. 3) is dominated by an orderly set of fractures that cross the entire core. Although the fractures are oriented $70^{\circ}$ to $80^{\circ}$ to the core axis, resulting in an apparent geometry of near-horizontal conjugate shear sets, the sense of shear could not be determined. 


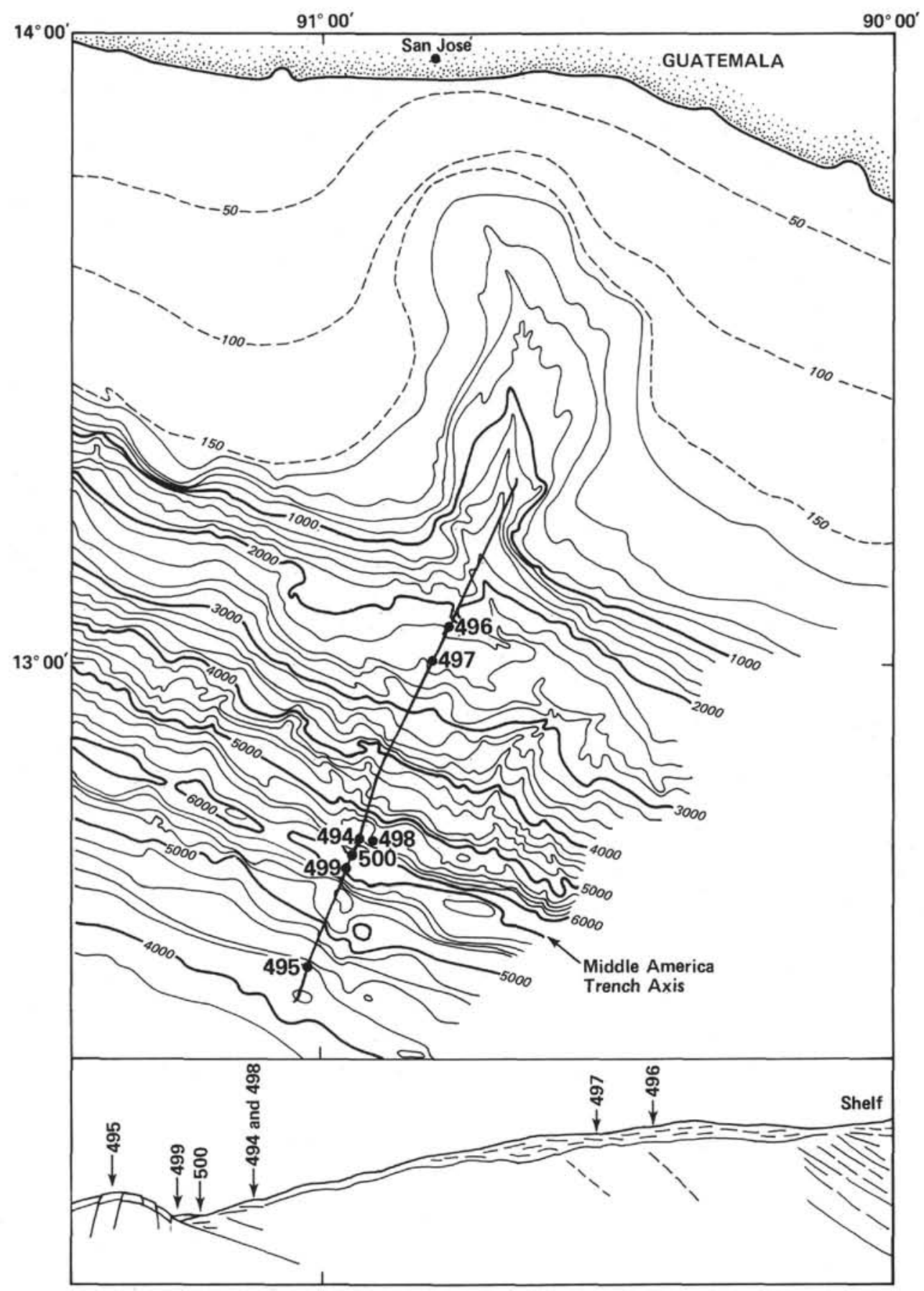

Figure 1. Location of Leg 67 sites.

Their lack of symmetry with respect to the core axis indicates that these are tectonically induced fractures. Partially healed fractures, in the upper part of the core, also support a tectonic origin.

\section{Hole 500, Trench Floor}

The first eleven cores from this hole are essentially devoid of any structures. In Core 11 the lithology changes from Quaternary muds and trench-fill turbidites to lower Miocene nannofossil-foraminiferal chalks. The in- tervening section of sediments, which is missing, could be explained if the muds and turbidites are placed in fault contact with the chalks or, similarly, if the muds and turbidites were deposited against a fault scarp in the chalks. Drilling breccias are common in Hole 500, being most noticeable in Sections 500-13-1 (Fig. 4), and 50015-1 through 500-15-3, and Sample 500-16,CC (1). Bedding in both the turbidites and chalks is near horizontal. In Section 500-13-2 (Fig. 4), two small reverse faults, with displacements less than $0.5 \mathrm{~cm}$, are present, as well 


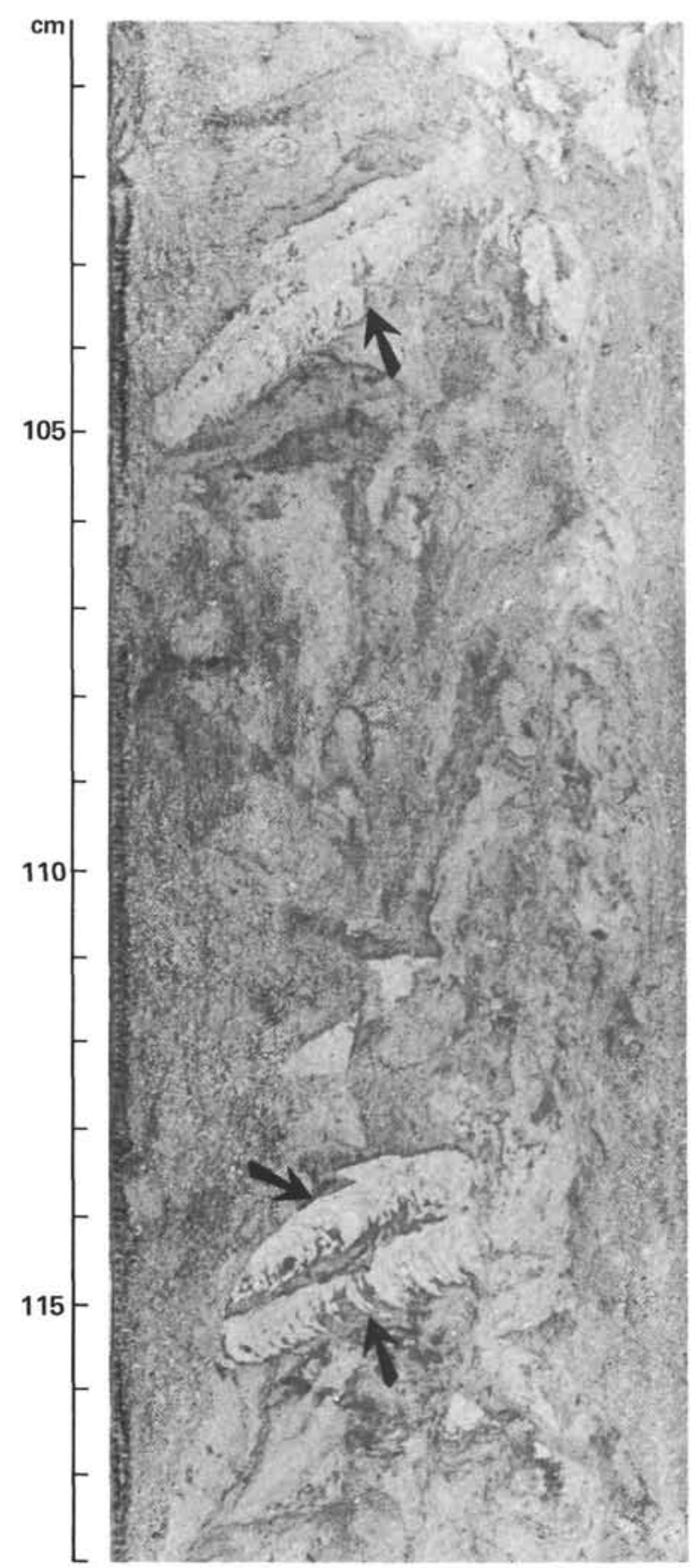

A

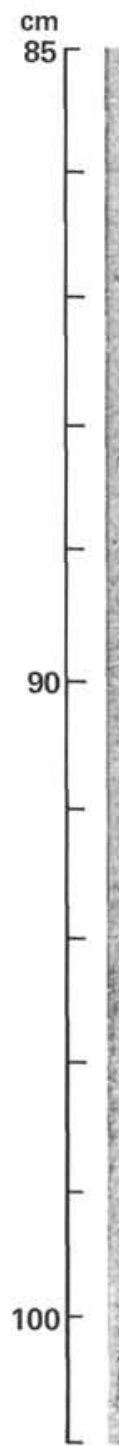

B

Figure 2. A. Bioturbated siliceous muds from Section 495-17-1. (The arrows point to the well-preserved burrows.) B. Bioturbated siliceous muds from Section 495-17-6. (The arrows show the sense of shear on two reverse faults that cross the undisturbed part of the core.)

as near-vertical fractures. These faults are most likely the result of soft-sediment deformation, as they are contained within depositional interfaces.

The intensity of deformation increases in Section 50014-1 (Fig. 4). Brittle fracture dominates the core, and a well-developed, slickensided, normal fault was found at the interval between 105 and $110 \mathrm{~cm}$. This fault has an orientation of about $37^{\circ}$ to the core axis. In this section of core the deformation is clearly a result of tectonic loading. Drilling biscuits (refer to the Appendix for a definition of these) are present, and between these some remolding of the sediment has occurred.

\section{Hole 494A, Lower Slope}

Throughout all of the sedimentary section at Hole $494 \mathrm{~A}$ there are scattered segments of core that are highly deformed. The deformation is mostly brittle fracture and has perhaps attributed to the low core recovery for this hole (about $30 \%$ ). Drilling effects are severe and are noticeable throughout the shallow cores, becoming more 


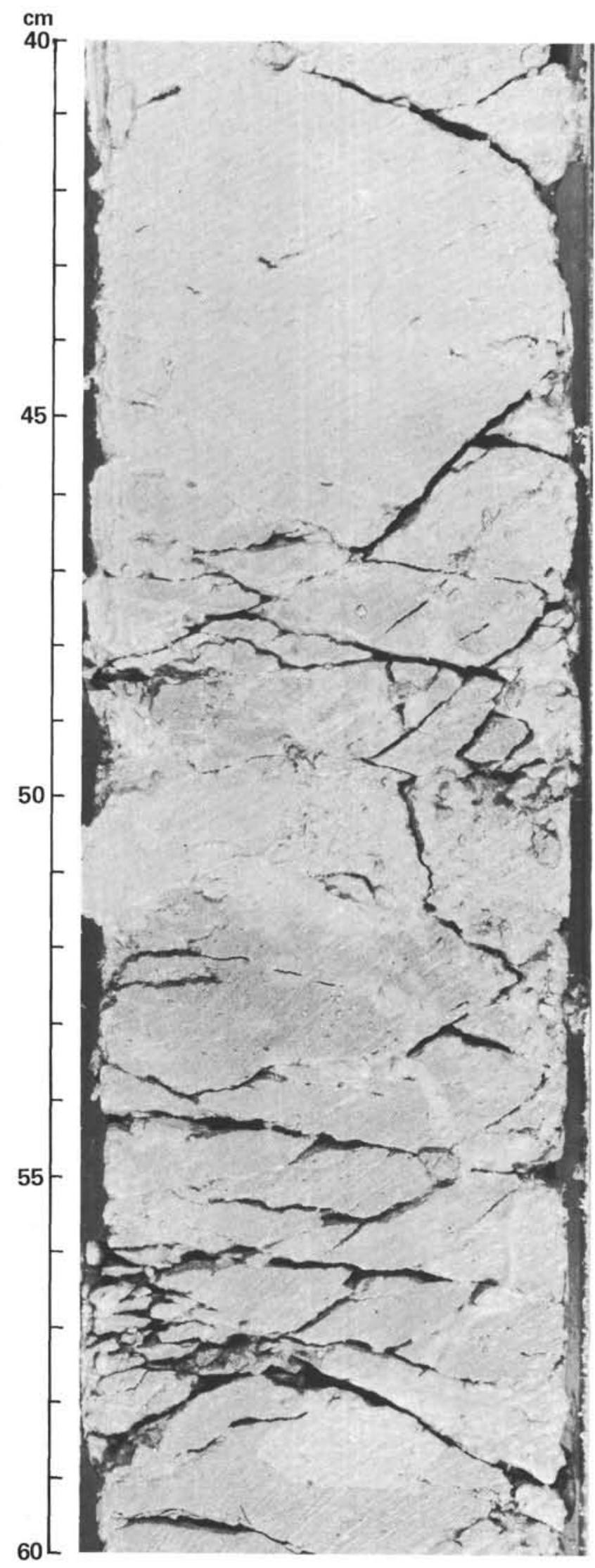

Figure 3. Tectonically induced near-horizontal shear fractures in the lower Miocene chalk from Section 495-30-1. pronounced at and below Core 17. Section 494A-17-1, which is a Pliocene mudstone, has at an interval between 81-108 cm (Fig. 5) progressively offset, thin, light-colored, coarse-grained laminations that have been offset in a left-lateral sense. These laminations may represent bedding. The laminations are offset by darker, sigmoidal shaped veinlets. In the interval between 89 and $94 \mathrm{~cm}$, a coarse-grained lamination, inclined $30^{\circ}$ to the core axis, may also be indicative of bedding. The remaining part of this core segment (Fig. 5) has healed fractures and small veins, both of which are compatible with tectonic-induced deformation. Section 494A-22-2 (Fig. 6), which is a middle Miocene pebbly mudstone, has fractures oriented normal to the core axis. These fractures are spaced at about 4 to $7 \mathrm{~cm}$ from each other and are most likely the boundaries of drilling biscuits (slickensides were observed, indicating the rotational shearing produced during drilling). Nevertheless, this core is distinct from all others in that it has an axially symmetric swirling, which is recorded by color variations and small dessication cracks. Whether or not these features are a response to drilling remains uncertain. If not, this sediment responded to the deformation in a manner unlike all other sediments from this hole. Noticeable also within this mudstone are subangular fragments of limestone, which themselves are devoid of any fracturing. Core 27, Section 1 (Fig. 7), an Eocene mudstone with irregularly distributed layers of lighter calcareous mudstone, has undergone intense brittle deformation. Two probable stages of deformation characterize these sediments. The first and less pronounced of the two is soft-sediment deformation. It is recorded by irregular flow and a chaotic distribution of the lighter calcareous fragments and layers. The second and more pervasive stage of deformation is the brittle response of the sediment, including minor rigid body rotation of the constitutive particles. Both healed and open fractures are found within this core and are inclined at about $30^{\circ}$ to $40^{\circ}$ to the core axis. The healed fractures have within them less than 1-mmthick zones of darker cohesive material. Shear fractures, oriented $50^{\circ}$ to $70^{\circ}$ to the core axis, cross the entire core, again indicative of tectonic deformation. Small displacements (about $2 \mathrm{~mm}$ ) recorded by offsets of the light calcareous material indicate extension normal to the core axis (Fig. 7, interval $70-80 \mathrm{~cm}$ ).

No structural features were observed in the remaining part of the sedimentary sequence. In many instances, all that was recovered was drill breccia, mostly below Core 17 (in Sections 494A-28-1 and 494A-30-1, and Sample 494A-31, CC.)

\section{Holes 496 and 497, Slope}

These holes will be discussed together, as the structural feature of interest is common to both. Although drilling-induced fractures and breccias are frequent in both holes (e.g., Hole 496, Core 36 and Hole 497, Core 29 ), of interest in these slope sites are the near-vertical, sigmoidal shaped veinlets ${ }^{2}$ (Fig. 8). These are contained

\footnotetext{
${ }^{2}$ A thorough analysis of the veinlets is not presented here, as they are discussed in detail by Darrel Cowan in this volume.
} 


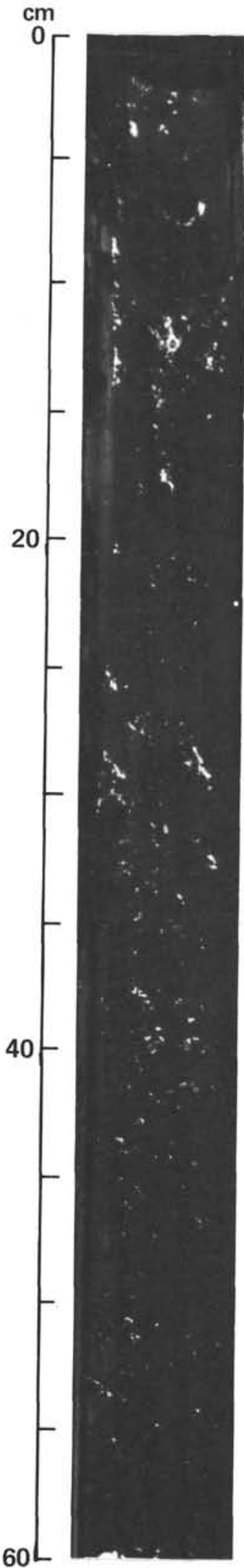

13-1

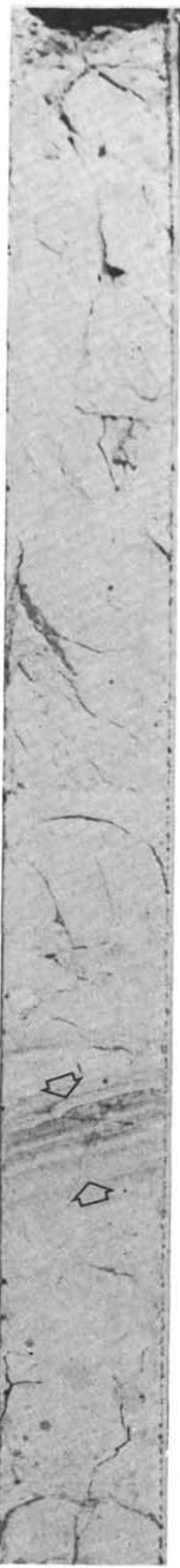

13-2

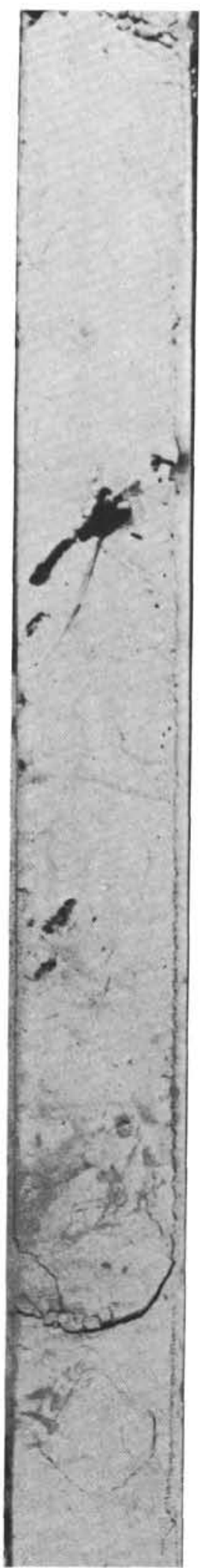

13-3

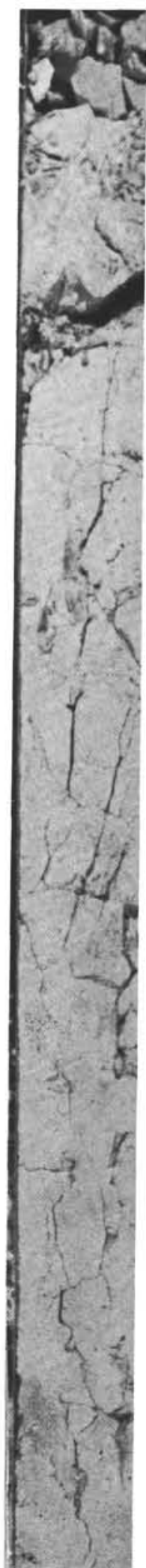

14-1

Figure 4. Cores from Hole 500 showing drilling breccias (Core 13, Section 1) overlying the competent lower Miocene chalk (Core 13, Section 2); the two reverse faults contained within depositional interfaces (shown with hollow arrows, Core 13, Section 2); and the normal fault at the base of Core 14, Section 1 (arrows show sense of shear). (Note the increase in fracture intensity from Core 13, Section 3 to Core 14 , Section 1.) 


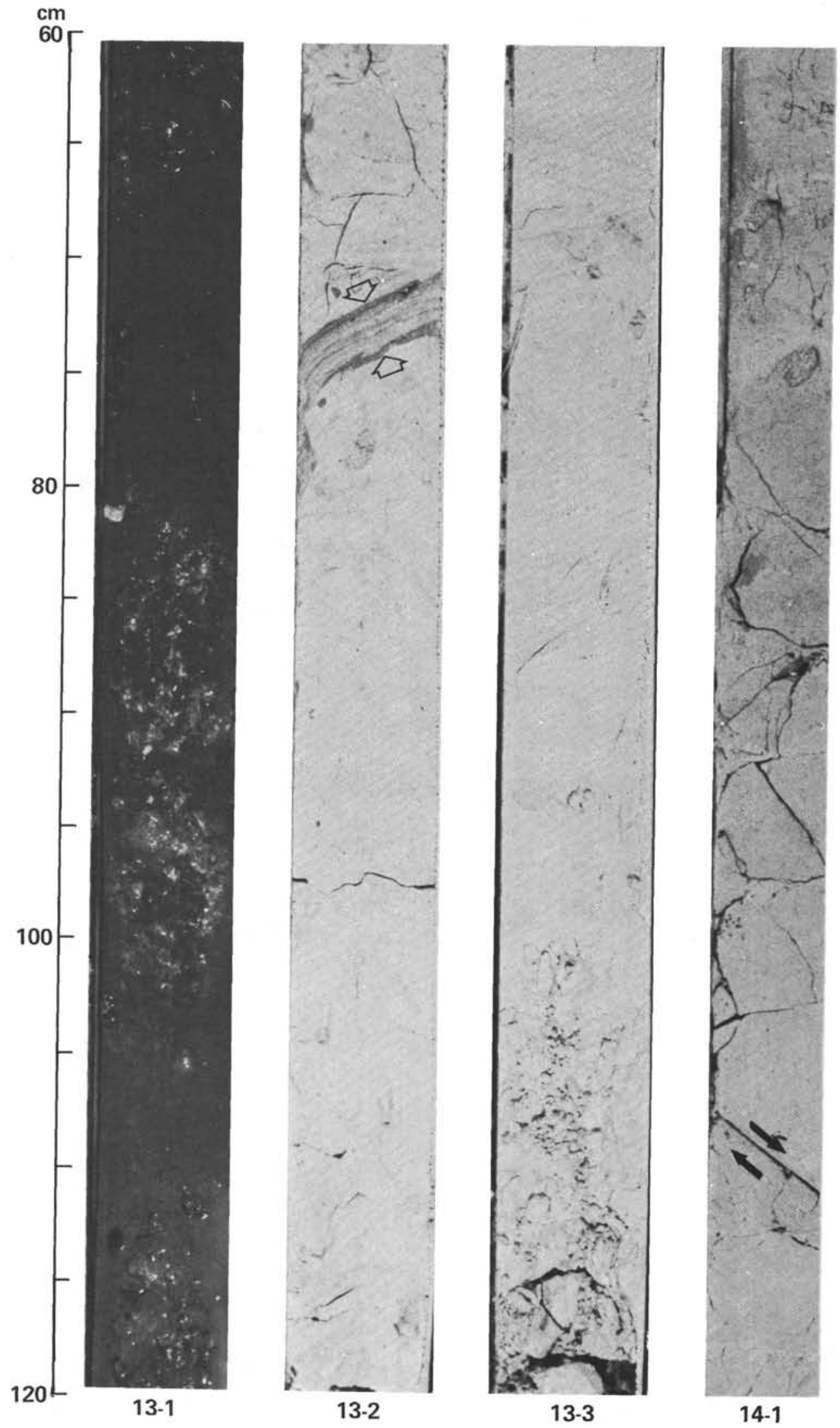

Figure 4. (Continued). 


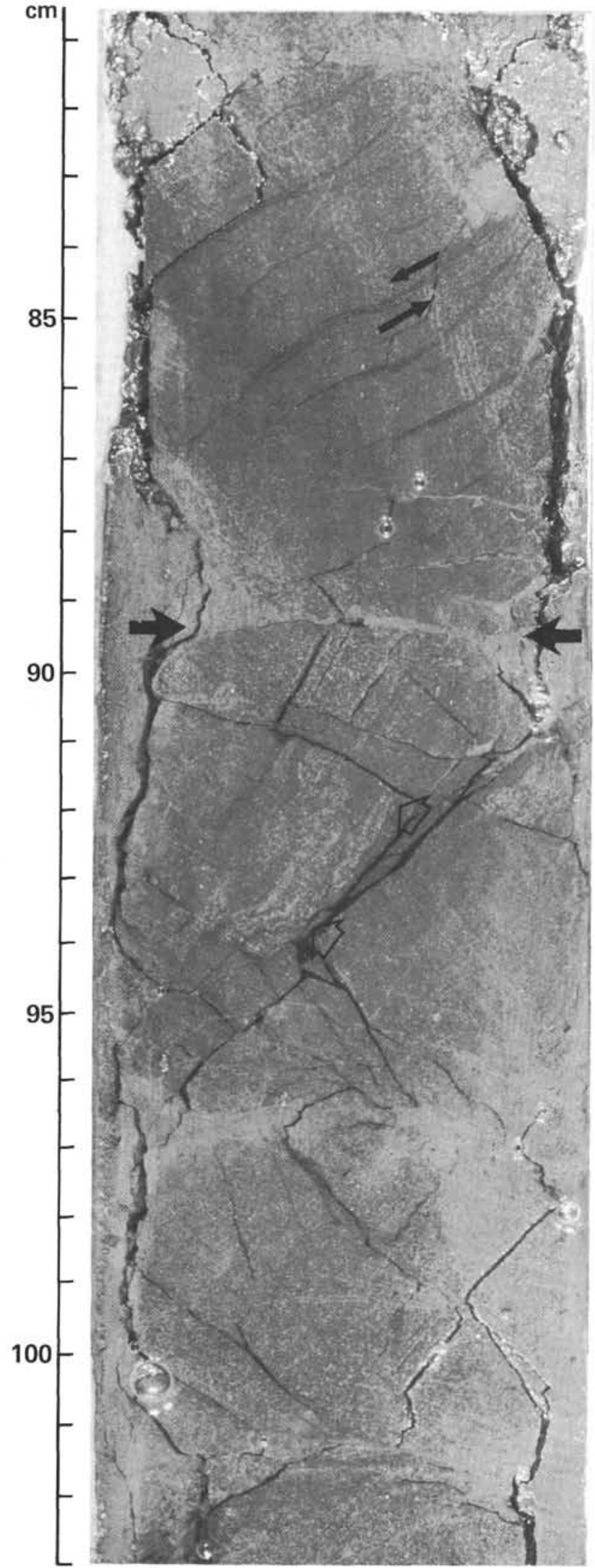

Figure 5. Pliocene mudstone from Section 494A-17-1. (Thin arrows show left-lateral offset of coarse-grained [bedding?] laminations caused by slip on sigmoidal veinlets. The hollow arrows [interval $89-94 \mathrm{~cm}$ ] point to possible bedding laminations. Bold arrows mark a drilling biscuit boundary.)

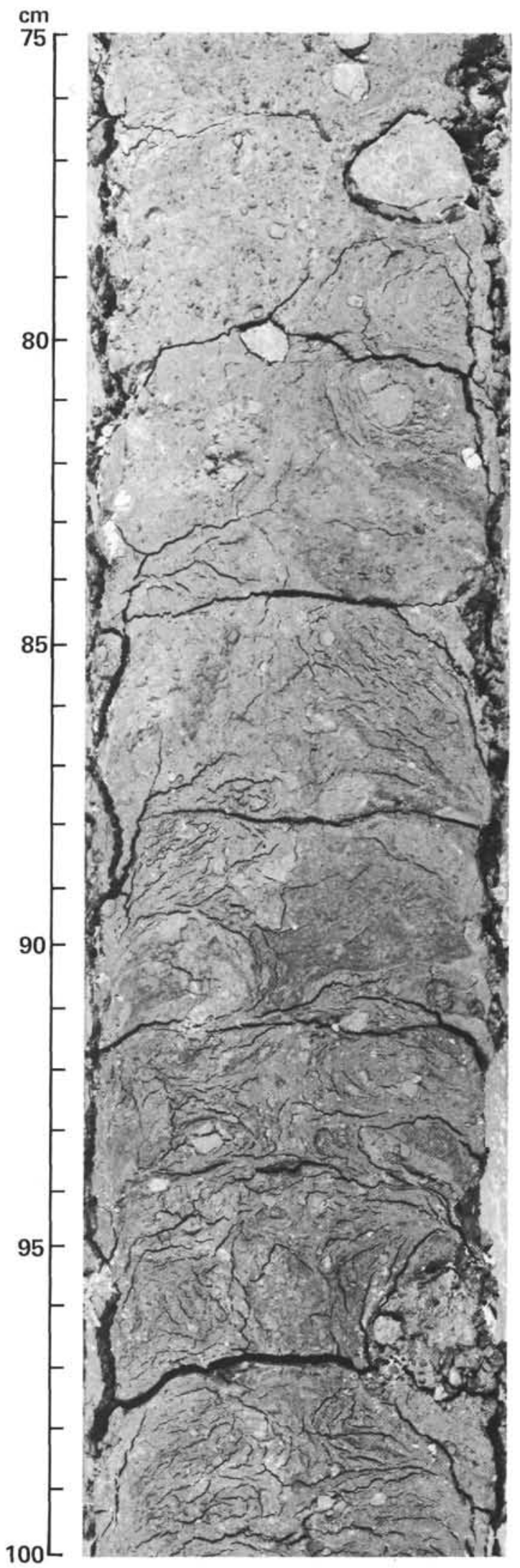

Figure 6. Early Miocene pebbly mudstone from Section 494A-22-2. (Note the swirling and dessication cracks that are contained within horizontal fractures separating the core into drilling biscuits. Unfractured angular pieces of limestone are seen throughout the core.) 


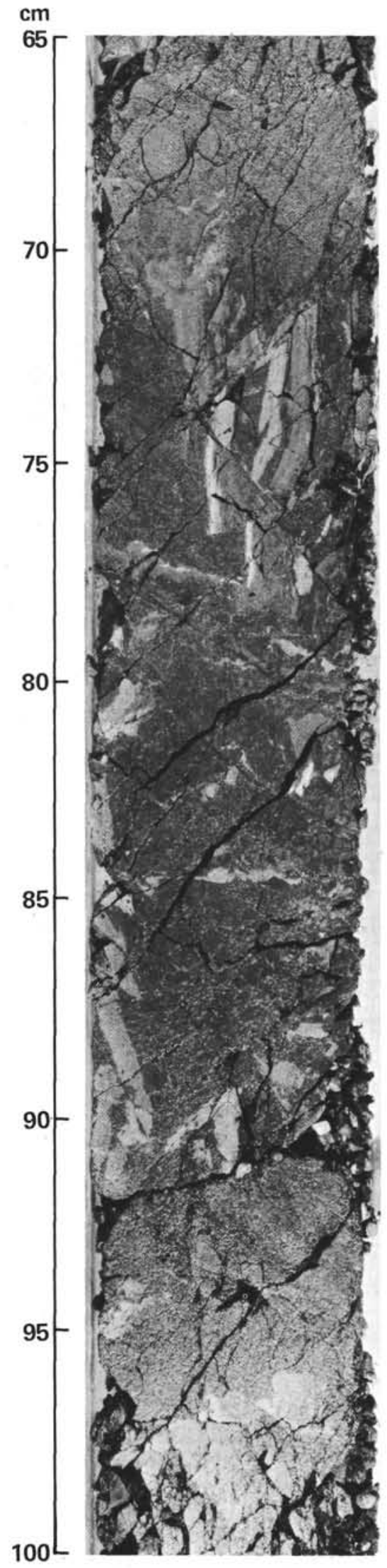

Figure 7. Eocene mudstone from Section 494A-27-1 showing irregular flow of light calcareous fragments and layers, as well as intense brittle deformation throughout the entire core.

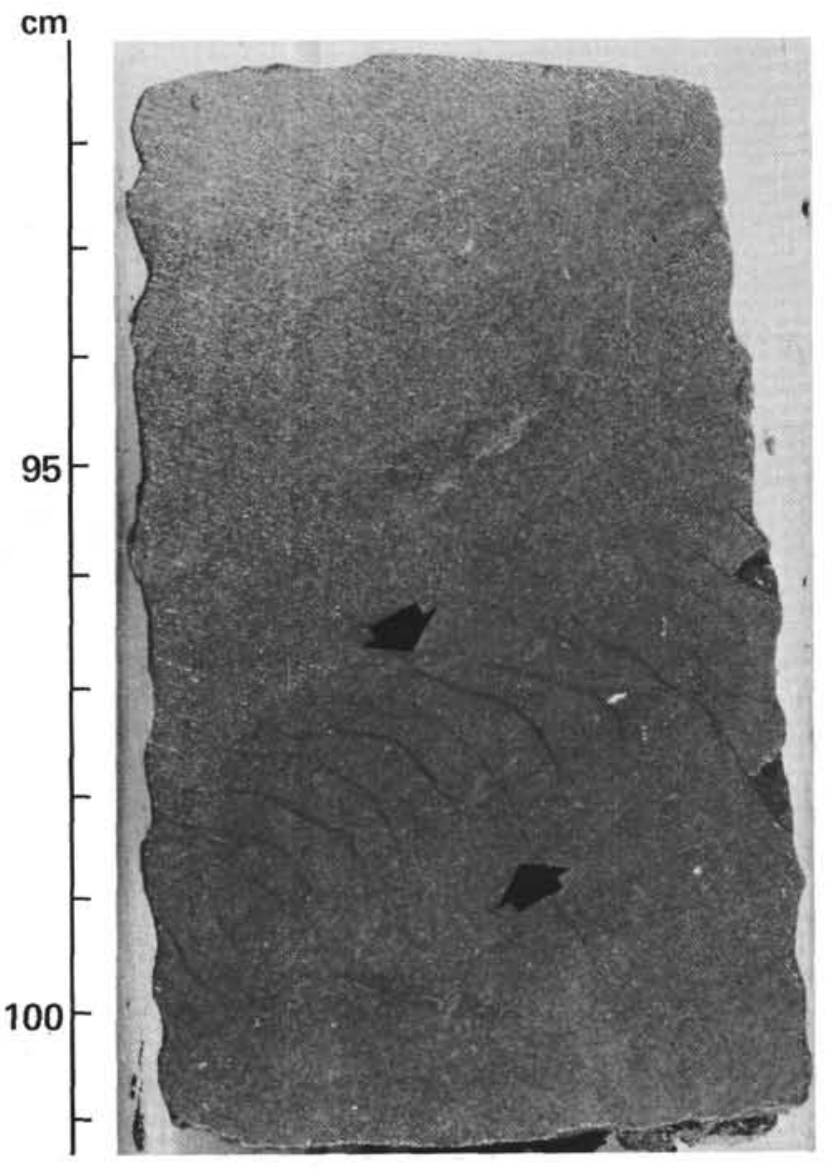

Figure 8. Example of near-vertical sigmoidal veinlets (shown in the zone between the arrows) from Hole 496, Core 36.

mostly within a semilithified mudstone that underlies an unconsolidated hemipelagic mud. Coarse-grained material (perhaps bedding laminations) with an apparent dip of $35^{\circ}$ to the core axis bound zones of finer-grained sediment containing the veinlets. If the coarse, sandy material is bedding, then the veins cannot be interpreted as distorted bedding planes, because these two are almost normal to each other. The lack of any symmetrical relationship with the core axis precludes these veinlets from being drilling-induced features. The filling of the veinlets by the darker sediment suggests that fluids may have migrated through them.

\section{Interpretation}

Seaward of the trench, the structures in the cores indicate that in general the deformation is dominated by shear fracturing and to a lesser extent faulting. It is difficult to determine whether the reverse faults described for Holes 495 and 500 are the result of soft-sediment deformation or of tectonic loading. The two in Hole 500 are contained within depositional interfaces and as such imply some relationship to sedimentary processes. The apparent orientation of the fractures in Core 30 , Section 1 of Hole 495 suggests compression normal to the core axis. The interpretation of these features is tenuous, because most of the deformation, interpreted as being definitely of tectonic origin, suggests extension normal to 
the core axis (particularly the well-developed normal fault in Hole 500).

Holes 495 and 500, on the seaward slope and trench, respectively, record the highest intensity of deformation in the lower Miocene chalks. At Hole 495, fracture density increases at the beginning of Core 30 . This change in intensity permits us to divide the sequence into at least two mechanically distinct units. The first is the less competent and relatively unconsolidated muds to a subbottom depth of about 275.5 meters (Cores $29 / 30$ boundary). The second is that of the remaining sediments-the chalks. The chalks, therefore, form the part of the sedimentary sequence that has supported most of the tectonic stress.

At Hole 500 the intensity of deformation in the lower Miocene chalks again allows us to divide the sedimentary sequence into two mechanically different units. Although here there are the incompetent loose muds underlain by the more competent brittle chalks, the chalks themselves can be subdivided so that those below Core 13 are the more brittle (and load-bearing) part of the sequence. This breakdown is made more definitive because of a change in physical properties. GRAPE densities increase at the cores $13 / 14$ boundary, where Core 13 has an average density of $1.55 \mathrm{~g} / \mathrm{cm}^{3}$ and Core $14 \mathrm{a}$ value of $1.75 \mathrm{~g} / \mathrm{cm}^{3}$ (Table 1 ).

The landward slope sediments lack any evidence of horizontal compressive tectonism. If anything, the small displacements observed in Core 27, Section 1 (Hole 494A) indicate extension normal to the core axis. In Hole 494A the deformation is not restricted to any given part of the section (such as in the lower Miocene chalks of the other holes discussed). The recurrence of drill breccias may be related to faulting or, alternatively, to slumping. The slope is in general characterized by the sigmoidal veinlets described for Holes 496 and 497. These will be discussed in more detail in a later section.

Physical property data obtained on board ship demonstrate that overall the sediments have high porosities and water content. Table 1 shows porosity values for three cores from Hole 494A, and these have values of $55 \%$. Porosity data for the lower Miocene chalks and mudstones from the other cores described are not available. Nevertheless, Hamilton (1976) has constructed plots of porosity versus depth for different deep-sea sediments; on the basis of these trends, the porosities for the sediments, at depths equal to those of the chalks and the mudstones, are: $45 \%$ to $60 \%$ for chalks; $60 \%$ to $80 \%$ for pelagic clays; $70 \%$ to $80 \%$ for diatomaceous ooze; and $40 \%$ to $60 \%$ for terrigenous mudstone (from Japan). On the basis of percent dry weight (Table 1), water content for the sediments recovered ranges from 30 to $190 \%$.

The high porosities and water content are important intrinsic properties of the sediments and as such must affect the manner by which they deform. Thus an examination of the effect these properties have on deformation was the basic motivation for conducting the laboratory experiments described in the following section.

\section{EXPERIMENTAL PROCEDURE AND RESULTS}

The proposed program of analyzing the mechanical strength of representative sediments from all of the holes drilled could not be done because (1) in most instances the core was not sufficiently indurated to permit sampling or (2) the core was too fractured to permit obtaining a sample of adequate size (e.g., Holes 494A and 500). Only eight samples from Hole 495 and two from Hole 499B were experimentally deformed.

In view of the high porosities and water content, it seemed desirable to investigate differences in behavior between dry and water-saturated samples. The high porosities suggest that a significant amount of pore space collapse would occur in the samples deformed dry upon the application of the hydrostatic and differential stress. In the saturated samples (if kept undrained during the test) the pore fluid pressure would approximate that of the confining pressure, and the effective pressure would be zero. The pore fluid would act like a rigid framework and prevent the pore space from collapsing. At equal confining pressure, the mode of failure for the dry and saturated samples should therefore differ.

The experimentally imposed stresses may not necessarily be comparable to those in nature. In all cases the maximum principal compressive stress is parallel to the core axis (i.e., equivalent to having the maximum stress vertical in nature). Also, the saturated samples were deformed undrained, which may not be an accurate representation of the natural situation. Experimentally, it is the easiest way to reduce the effective stress. By no means are these experiments intended to simulate actual conditions, as these cannot presently be assessed. The experimental results are valuable only in that they define relative differences in the mechanical behavior of the specimens, which should parallel the relative behavior of comparable rocks in nature. Our experimental procedure is summarized as follows.

\section{PROCEDURE}

Triaxial compression experiments are conducted on right circular cylinders (minicores) obtained on board Glomar Challenger. The samples, $2.5 \mathrm{~cm}$ in diameter and about 5 to $6 \mathrm{~cm}$ in length, were deformed air dried or water saturated (undrained) at confining pressures ranging from 1 to $100 \mathrm{MPa}$, room temperature, and a strain rate of $10^{-4} \mathrm{~s}^{-1}$. A range of confining pressure from 1 to $100 \mathrm{MPa}$ was selected in order to investigate a broader spectrum of behaviors. Admittedly though, a confining pressure of 70 to $100 \mathrm{MPa}$ far exceeds that of the effective confining pressure at any of these sites. A range of 35 to $70 \mathrm{MPa}$ confining pressure (approximately 5,000-10,000 psi) was selected in order to compare directly these results with those obtained by Smith and Forristal (1973) for triaxial compression experiments on other deepsea sediments. The rock-deformation apparatus used is fully described by Handin and others (1972). Because the minicores were obtained after the core liner was cut in half, their axes are in all cases parallel to those of the main cores. The ends of the assembled samples are surface ground with an 80-grit wheel and are parallel to within $0.03 \mathrm{~cm}$. Three polyolefin jackets are used to isolate the sample from the confining fluid (a mixture of kerosene and oil). Because of the limited number of samples available, only two experiments were repeated for reproducibility. Reproducibility of differential stress is $4 \%$ at $20 \%$ strain. The data are originally recorded as force-axial displacement curves, which are then converted to differential stress (maximum compressive stress minus confining pressure)-strain curves.

\section{Data}

Samples deformed, corresponding confining pressures, and the resultant mode of failure are listed in Table 2.The majority of the samples are from Hole 495, and only two are from Hole 499B. In a way it is fortu- 
Table 2. Summary of triaxial experiments ${ }^{\mathrm{a}}$.

\begin{tabular}{cccc}
\hline Confining & $\begin{array}{c}\text { Effective } \\
\text { Confining }\end{array}$ & \\
Hole, Core-Section & $\begin{array}{c}\text { Pressure } \\
\text { (sub-bottom depth in } \mathrm{m})\end{array}$ & $\begin{array}{c}\text { Pressure } \\
(\mathrm{MPa})\end{array}$ & $\begin{array}{c}\text { Mode of } \\
\text { Failureb }\end{array}$ \\
\hline
\end{tabular}

Hole 495

\section{8-2}

saturated

(354.9)

41-2

(380.9)

42-1

saturated

(390.5)

$42-4$

saturated

(395.4)

43-3

$(402.8)$

43-3

$(403.1)$

44-4

$(413.4)$

44-6

(414.5)

Hole 499B

$8-2$
$(290.9)$
$8-3$
saturated
$(292.4)$

\section{$8-2$}

(292.4)

70

Ductile

50

$0 \quad$ Transitional

a Samples deformed are all lower Miocene chalks. All experiments were done at room temperature and a strain rate of $10^{-4} \mathrm{~s}^{-1}$. All were tested room dry unless stated otherwise.

b Failure modes are defined in the following manner: ductile, if the sample was deformed by homogeneous macroscopic flow; transitional, if the sample was deformed along numerous slip planes but still with some ductility; and brittle, if the sample failed by one or more thoroughgoing rupture surfaces and with no ductile deformation.

itous that most of the samples are from Hole 495, as it is possible to study in more detail the properties of the sediments that have not yet been transported into the trench, and to see how these properties change as the sediments approach the trench. Results for dry specimens from Hole 495 all show similar trends (Fig. 9A). First, there is an almost linear increase in strain with no appreciable increase in differential stress. The magnitude of this linear increase (i.e., volumetric strain [compaction]) increases with higher confining pressures. Second, once the yield point is reached, all of the samples, except the one deformed at $1 \mathrm{MPa}$ confining pressure, continually strain harden until the tests are stopped.This behavior at high strain levels (up to $25 \%$ ) was also observed by Smith and Forristal (1973) for calcareous sediments. The samples all deformed in a ductile manner, ${ }^{3}$ except the one at $1 \mathrm{MPa}$ confining pressure, which failed in a brittle to transitional (semibrittle) fashion.

\footnotetext{
${ }^{3}$ The mode of failure discussed for all experimentally deformed specimens is based on the macroscopic deformation observed in the specimens and not on the form of the stressstrain curves.
}

Three other samples from Hole 495 were deformed water-saturated at confining pressures equal to those discussed above, i.e., at zero effective confining pressure. Comparing these results (Figure 9B) with those deformed dry, a considerable strength reduction in the saturated samples is observed. These results are expected because the effective pressure is essentially zero, and therefore the curves are similar to that for the sample deformed dry at $1 \mathrm{MPa}$ confining pressure. The curves show a small amount of strain hardening after which they deform in a steady-state manner. A small linear increase in strain, with no increase in stress, also is observed in these experiments. The failure mode for all wet tests is transitional as opposed to the dry samples which are all ductile.

Two samples from Hole 499B were deformed, one dry at a confining pressure of $70 \mathrm{MPa}$ and the second water-saturated at $50 \mathrm{MPa}$ confining pressure (Fig. 10). Their response was ductile and transitional, respectively. Both experiments follow the same trends as those discussed for the samples from Hole 495. The sample deformed dry has a higher strength, at 70-MPa confining pressure, than does the one from Hole 495, at 100MPa confining pressure. Likewise, the saturated sample has a slightly higher strength than does its counterpart from Hole 495.

\section{Interpretation}

Two distinct trends are observed in the samples of chalk deformed dry and those deformed water-saturated. The amount of strain in the rock, prior to its supporting any load, increases with increasing confining pressure in the dry samples. This is interpreted as a collapse of the pore space upon the application of hydrostatic stress. The samples deformed wet also show a small amount of strain with no increase in the stress level, suggesting these samples were not completely saturated. Nevertheless, very low stresses are required to deform these samples. Equally important is the fact that their brittle behavior increases as the effective confining pressure decreases.

These trends suggest that the brittle phenomena observed in the seaward slope sediments, as well as in those in the trench, may be largely due to very low effective overburden pressures. Smith and Forristal (1973) concluded that the in situ brittle fracture observed in the cores recovered from Leg 20 was most likely the result of the pore fluid pressure being almost as high as the confining pressure (their conclusions apply to sediments even as indurated as cherts).

Because of the intrinsically high water content and porosities in deep-sea sediments, it is not unreasonable to expect that failure of these sediments will always be facilitated by pore pressures nearly equal to the confining pressure. Yet for the sediments studied here, pore fluid pressures need not be the only cause promoting embrittlement. If these sediments are subject to extension (as may happen because of bending of the subducting plate), the imposed extensional stress will also enhance the brittle field (Heard, 1960). 

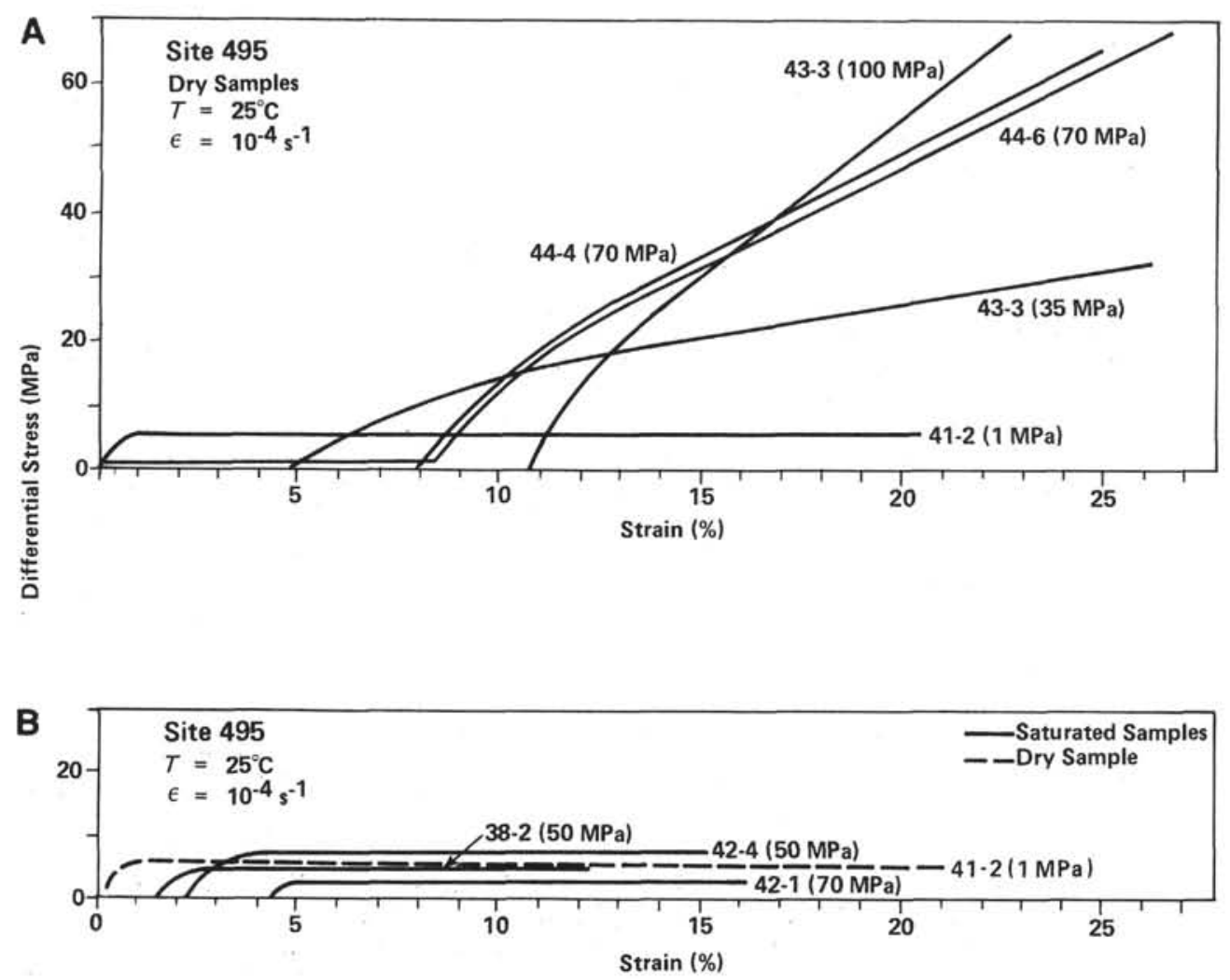

Figure 9. Differential stress-strain curves for deformed samples from Hole 495. (The core and section and confining pressure [MPa] are shown for each curve.) A. Curves for samples deformed dry. B. Curves for samples deformed water-saturated. (The curve for the sample deformed dry at $1 \mathrm{MPa}$ confining pressure is included for purposes of comparison.)

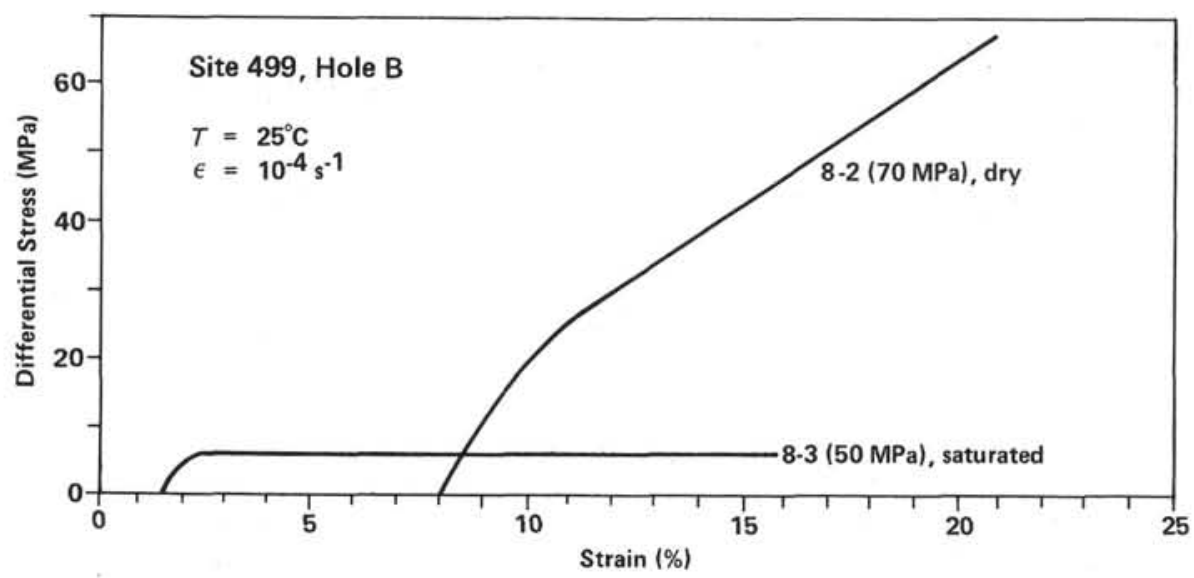

Figure 10. Differential stress-strain curves for samples from Hole 499B deformed both dry and water-saturated.

\section{DISCUSSION}

The visual core inspection indicates that (1) deformation in the trench and seaward slope sediments is primarily extensional and dominated by brittle failure, and (2) there is little evidence of horizontal shortening of the landward slope sediments. Brittle failure also dominates the landward slope sediments; in these sediments gas hydrate may have contributed significantly to the deformation.

\section{Deformation of the Seaward Slope and Trench Sediments}

Extensional tectonics prevail on the seaward slope and within the trench axis. Isacks et al. (1968), Hanks (1971), Hilde and Sharman (1978), Caldwell et al. (1979), Isacks and Barazangi (1979), and others have proposed that bending of an elastic oceanic plate, as it is subducted, results in extension of the upper part of the plate. The normal faulting observed from Holes 495 through 
500 is compatible with this interpretation. In these sediments, low effective pressures may greatly facilitate brittle failure. The imposed extensional stress will also contribute to enhancing the brittle behavior of the sediments. Seismic records (Ladd et al., 1978; Ibrahim et al., 1979) and the structural features observed in the cores support a model in which normal fault-bounded blocks are transported into the subduction zone. The displacements along these faults can range from about 100 meters (measured for Hole 500) to as much as 400 to 800 meters (Hilde and Sharman, 1978). Accordingly, this interpretation also implies that if the sediments are offscraped and accreted to the slope, and if accretion is accomplished by nonpervasive sediment transfer along the master thrust fault alone, thrust faults higher in the deforming continental margin ought to bound sediments that are internally normal faulted. Structures interpreted from seismic records would not be continous, nor would there be an orderly velocity profile.

The results from Leg 67 show that structures indicative of tectonic horizontal compression are not dominant. The reverse faults and the fracture orientation (Section 495-30-1) are the only macroscopic features that reflect deformation produced by horizontal shortening. These features seem to be anomalous, however, in light of the overwhelming evidence that favors extensional tectonics.

There are, nevertheless, subtle changes in the sediment properties as they pass through the trench, which could be interpreted as the result of tectonic compression. For instance, the lower Miocene chalks from Hole 495 have GRAPE densities of 1.3 to $1.6 \mathrm{~g} / \mathrm{cm}^{3}$ and water content (based on \% dry wt.) of about $190 \%$ (Table 1). At Hole 499B, the chalks have a density of $1.65 \mathrm{~g} / \mathrm{cm}^{3}$ and a water content of $60 \%$ (see Site 499 report). At Hole 500, which is at the base of the landward slope within the trench, the corresponding values are 1.55 to $1.75 \mathrm{~g} / \mathrm{cm}^{3}$ and $45 \%$ to $49 \%$ (Table 1 ). Although the data from Site 499 are few, they do fit the trends - an increase in density and a decrease in water content as the sediments approach the base of the landward slope. No triaxial tests were done on samples from Hole 500. Yet a comparison of the samples deformed experimentally from Holes 495 and 499B shows that, everything else held equal, a higher differential stress is required to deform the samples from Hole 499B. The changes in density, water content, and mechanical strength are most likely a result of mechanical compaction due to tectonic compression. These changes could not result from either diagenetic compaction or an increase in sediment overburden. There are no significant environmental changes between Holes 495 and 500 to alter the diagenesis of the sediments. Because sediment overburden is not appreciably greater at Hole 500 than it is a Hole 495, it could then be argued that an increase in the water column at Hole 500 could increase the overburden pressure. But it has been shown experimentally (in the previous section) that the effective pressure at both sites is exceedingly low. That is, the water of the overlying column may exchange with the pore fluids such that the effective pressure is essentially zero. Hence differences in water depth do not produce differences in effective pressure. Tectonic compression is therefore the most attractive cause. As there are no compressional features that can definitely be discerned from the seismic records and the cores, it may be concluded that the differential stress only promotes compaction and is below the yield strength required to cause macroscopic failure in these sediments.

\section{Gas Hydrate and the Deformation of the Landward Slope Sediments}

Drilling objectives were not met on the landward slope because high gas concentrations and gas hydrate necessitated that the holes be abandoned. Thus we did not reach the sub-bottom depths that are required to resolve the slope structure.

The sites on the slope (particularly 496 and 497) are characterized by a sequence of unconsolidated hemipelagic muds underlain by a semilithified mudstone. The gas hydrate occurs below the mudstone in a vitric sand matrix. Fracturing is present within the mudstone as are the sigmoidal, near vertical veins, which produce a penetrative fabric throughout the slope.

There is much to understand about the effects that gas hydrate may have on sediment deformation. Indications exist, not only from the slope sediments drilled on Leg 67 but from other DSDP legs as well, like Leg 11 (Lancelot and Ewing, 1972), Legs 56 and 57 (Arthur et al., 1980), and Leg 66 (Shipley et al., 1979), that gas and/or the decomposition of gas hydrate may cause significant deformation of unconsolidated hemipelagic muds. For instance, on Leg 11, at Site 106, indirect evidence for the vertical migration of gas was found in the form of vertical fractures and "burrowlike" structures (Lancelot and Ewing, 1972). On Legs 56 and 57, across the Japan Trench, veins and vertical fractures were observed in the slope sediments. Although these features were interpreted as being the result of overpressurization caused by tectonic loading of accreted sediments, Arthur et al. (1980) state that hydrocarbons migrated through parts of the fracture system. Barnes and Ross (1975) outlined the structural implications of gas hydrate in deep-ocean sediments. They state that if connate waters form part of the solid phase in the hydrate, fracture cleavage will develop without the formation of earlier slaty cleavage. Upon melting of the hydrate to water and gas, two situations are possible. First, if the deviatoric stress is small, a poor regional fissility may develop through gravitational compaction, depending on the orientation of the principal stresses. Second, if the deviatoric stress is large, overthrust faulting and buckling will develop. Similarly, Hedberg (1974) suggested that the decomposition at the base of the hydrate could cause mud diapirs, mud volcanos, and other phenomena of overpressuring.

One possibility to consider, in light of these arguments, is that the veins and fractures observed in Holes 496 and 497 are associated with gas/fluid overpressurization due to the decomposition of the hydrate. There are two factors that bear directly on this problem.

First, direct observations indicate that the hydrate occurs only in the vitric sands underlying the mudstones. Yet the fact that they were not observed in the mud- 
stones could be a function of a pore surface area/melting rate effect ( $\mathrm{J}$. Curiale, personal communication, 1980). Essentially, this means that as the mudstones are recovered, any hydrate in them will melt before that in the vitric sands because the smaller the pore size the greater the total surface area of the pore spaces. Furthermore, Heling (1970) states that similar sediments (shales) do have pore volumes large enough to hold clathrate (hydrate)-size molecules. That the hydrate is only found in the vitric sands is therefore not firmly established. In situ hydrate could also exist in the mudstones. Second, geochemical calculations show that melting of the hydrate (recovered on deck) liberates greater quantities of gas than are soluble in water at the in situ pressure-temperature conditions (von Huene, Aubouin, et al., 1980). These calculations also show that most of the landward slope is well within the stability field of hydrate. This stability field will vary if there are fluctuations in the pressure-temperature gradients. Very small changes in these gradients will be sufficient to decompose the hydrate (W. Harrison, personal communication, 1980). Uplift of the slope and/or a reduction of the overburden pressure, by downslope movement of the sediments, are two possible ways to modify the hydrate stability field.

Although the uncertainties are large, a conceptual model is proposed wherein uplift, removal of sediment overburden, or a combination of both forces the gas + water $\leftrightharpoons$ hydrate phase boundary to migrate deeper within the sediment column. Sediments that once contained hydrate (including perhaps the base of the mudstones) would contain gas and water. Because more gas is liberated than what is soluble in water, a temporary condition of overpressurization will develop. Also, if the upper sequence of mudstone does not have hydrate, it will act as a permeability seal and aid the overpressurization. The effective stress will become infinitesimal, but the tensile strength of the sediment will not be exceeded. If it were exceeded it would be analogous to hydraulic fracturing, and would produce a more random orientation of fractures and veins than what is observed. A small imposed deviatoric stress (gravitational compaction?) would be sufficient to fracture the highly embrittled sediment, after which degassing and dewatering will proceed.

Cowan (this volume) has studied the structural details of the sigmoidal veins observed in the slope sediments and suggests that they are produced by downslope creep of part of the blanket of slope sediments, rather than being a small-scale response to stresses near larger structures. Similarly, it is possible that the deformation of the slope sediments, if produced by decomposition of the hydrate, can be independent of the larger-scale deformation associated with this convergent margin.

\section{General Considerations about the Structure of the Middle America Trench}

The structural features discussed in this paper can be understood in terms of the basic principles governing rock deformation. The extensional features present in the seaward slope and trench sediments can be satisfac- torily explained according to the popular models in which extension will result because of bending of the subducting oceanic plate.

The transition zone between the trench and the landward slope is not satisfactorily understood, given the Leg 67 results. Most bothersome is the lack of observed deformation features indicative of tectonic horizontal compression, such as the folding shown to be associated elsewhere with underthrusting (Moore and Karig, 1976; Carson, 1977). Lower Miocene chalk was recovered in all of the holes drilled seaward of the landward slope, and it is within this unit that most of the deformation is observed. The lower Miocene chalks are missing on the landward slope. Instead, the Miocene sediments consist of blue gray mudstones and olive green slope deposits of an entirely different provenance.

The normal stratigraphic sequence observed in Hole 494A and the lack of continuity of sediment and deformation types across the trench-landward slope transition zone suggest that the accretion model of Seely et al. (1974) is not a convincing structural interpretation. The structural observations discussed in this paper support the preliminary interpretations (von Huene, Aubouin, et al., 1980) of subduction without accretion, subduction-erosion of a pre-Miocene accretionary complex, or a combination of both.

\section{CONCLUSIONS}

The following conclusions seem warranted from the results of this study:

1) The seaward slope and trench sediments differ in their deformation style from those on the landward slope. Sediment deformation in the seaward slope and trench is observed primarily within the lower Miocene chalks (at Sites 495, 499, and 500). Lower Miocene chalks were not recovered from the landward slope.

2) Although a minor occurrence of reverse faults (which may or may not be soft-sediment deformation) and fractures indicates horizontal compression, the bulk of the deformation seaward of the landward slope implies extension normal to the core axis.

3) Pore fluid pressures within the chalks reduce the effective overburden stress to near zero, facilitating brittle failure. A superimposed extensional stress, caused by subduction of an elastic oceanic plate, also enhances the brittleness of these sediments.

4) Physical property and mechanical strength changes suggest that as the lower Miocene chalks approach the trench, tectonic compression increases. The lack of macroscopic thrust faults or folds implies that the differential stress is low; promoting only compaction and not macroscopic failure.

5) Across the trench-landward slope transition zone and at the base of the landward slope there are no macroscopic deformational features indicative of horizontal compressive tectonism. The origin of the chaotic breccias and fractures in Hole 494A is not clearly understood.

6) The presence of fracturing and sigmoidol veins at the slope sites (Sites 496 and 497) may be due to overpressuring caused by the decomposition of the gas hydrate. This deformation does not necessarily have to be 
the result of the large-scale deformation associated with plate convergence.

7) The lack of continuity in sediment type and deformation across the trench-landward slope transition zone and the normal stratigraphic sequence observed at Hole 494A do not support a model of steady-state accretion. Instead, a combination of subduction without accretion and subduction-erosion of a pre-Miocene accretionary complex are more likely tectonic interpretations.

\section{ACKNOWLEDGMENTS}

I thank Melvin Friedman, Thomas Hilde, John Logan, and Darrel Cowan for reviewing and improving the original manuscript. Discussions with the Shipboard Party were very helpful, in particular those with Darrel Cowan, Richard Faas, William Harrison, and Joseph Curiale. I also thank the Center for Tectonophysics, Texas A\&M University, for the use of the experimental rock deformation equipment.

\section{REFERENCES}

Arthur, M. A., Carson, R., and von Huene, R., 1980. Initial tectonic deformation of hemipelagic sediment at the leading edge of the Japan convergent margin. In Scientific Party, Init. Repts. DSDP, 56, 57, pt. 1: Washington (U.S. Govt. Printing Office), 569-614.

Barnes, W. C., and Ross, J. V., 1975. Some structural implications of gas hydrates in deep-ocean sediments. Annu. Meet. Geol. Soc. Am., 7(7):989-990. (Abstracts with Programs)

Caldwell, J. G., Turcotte, D. L., Haxby, W. F., and Karig, D. E., 1977. Thin elastic plate analysis of outer rises. In Talwani, M., and Pitman III, W. C., (Eds.), Island Arcs, Deep Sea Trenches, and Back-Arc Basins, Maurice Ewing Series I, Am. Geophys. Union, p. 467 .

Carson, R., 1977. Tectonically induced deformation of deep sea sediment off Washington and northern Oregon: mechanical consolidation. Mar. Geol., 24:289-307.

Hamilton, E. E., 1976. Variations in density and porosity with depth in deep-sea sediments. J. Sediment. Petrol., 46:280-300.

Handin, J. W., Friedman. M., Logan, J. M., Pattison, L. J., and Swolfs, H. S., 1972. Experimental folding of rocks underpressure-buckling of single layer beams. In Heard, H. C., Borg, I. Y., Carter, N. L., and Raleigh, C. B. (Eds.), Flow and Fracture of Rocks. Am. Geophys. Union Monograph 16:1-28.

Hanks, T. C., 1971. The Kuril-Hokkaido Trench system: large shallow earthquakes and simple models of deformation. Geophys. J. R. Astron. Soc., 23:173-189.

Heard, H. H., 1960. Transition from brittle fracture to ductile flow in Solenhofen limestone as a function of temperature, confining pressure, and interstitial fluid pressure. In Griggs, D., and Handin, J. W. (Eds.), Rock Deformation. Geol. Soc. Am. Mem. 79: 193-227.

Hedberg, H. D., 1974. Relation of methane generation to undercompacted shales, shale diapirs, and mud volcanoes. Am. Assoc. Pet. Geol. Bull., 58:661-673.

Heling, D., 1970. Micro-fabrics of shales and their rearrangement by compaction. Sedimentology, 15:247-260.

Hilde, T. W. C., and Sharman, G. F., 1978. Fault structure of the discarding plate and its influence on subduction process. Trans. Am. Geophys. Union, 59:1182. (Abstract)

Ibrahim, A. K., Latham, G. V., and Ladd, J., 1979. Seismic refraction and reflection measurements in the Middle America Trench offshore Guatemala. J. Geophys, Res., 84:5643-5649.

Isacks, B., and Barazangi, M., 1979. Geometry of Benioff zones: lateral segmentation and downwards bending of subducted lithosphere. In Talwani, M, and Pittman III, W.C. (Eds.), Island Arcs, Deep Sea Trenches, and Back-Arc Basins. Maurice Ewing Series I, Am. Geophys. Union, pp. 99-114.

Isacks, B., Oliver, J., and Sykes, L. R., 1968. Seismology and the new global tectonics. J. Geophys. Res., 73:5855-5899.

Kieckhefer, R. M., Shor, G. G., Curray, J. R., Sugiarta, W., and Hehuwat, F., 1980. Seismic refraction studies of the Sunda Trench and forearc basin. J. Geophys. Res., 85:863-889.
Kulm, L. D., and Fowler, G. A., 1974. Oregon continental margin structure and stratigraphy: a test of the imbricate thrust model. In Burk, C. A., and Drake, C. L. (Eds.), The Geology of Continental Margins: New York (Springer-Verlag), pp. 261-283.

Ladd, J., Ibrahim, A. K., McMillen, K. J., Latham, G. V., von Huene, R., Watkins, J. E., Moore, J. C., and Worzel, J. L., 1978. Tectonics of the Middle America Trench offshore Guatemala. In International Symposium of Guatemala February 4 Earthquake and the Reconstruction Process, Guatemala City.

Lancelot, Y., and Ewing, J. I., 1972. Correlation of natural gas zonation and carbonate diagenesis in Tertiary sediments from the northwest Atlantic. In Hollister, C. D., Ewing, J. I., et al., Init. Repts. DSDP, 11: Washington (U.S. Govt. Printing Office), 791-800.

Minster, J. B., and Jordan, T. H., 1978. Present-day plate motions. J. Geophys. Res., 83:5331-5354.

Molnar, P., and Sykes, L. R., 1969. Tectonics of the Caribbean and Middle America regions from focal mechanisms and seismicity. Geol. Soc. Am. Bull., 80:1639-1684.

Moore, J. C., and Karig, D. E., 1976. Sedimentology, structural geology, and tectonics of the Shikoku subduction zone, southwestern Japan. Geol. Soc. Am. Bull., 87:1259-1268.

Seely, D. R., 1979. The evolution of structural highs bordering major forearc basins. In Watkins, J. S., Montadert, L., and Dickerson, P. W. (Eds.), Geological and Geophysical Investigations of Continental Margins. Am. Assoc. Pet. Geol. Mem. 29:245-260.

Seely, D. R., Vail, P. R., and Walton, G. G., 1974. Trench-slope model. In Burk, C. A., and Drake, C. L. (Eds.), The Geology of Continental Margins: New York (Springer-Verlag), pp. 249-260.

Shipley, T. H., Houston, M. H., Buffler, R. T., Shaub, F. J., McMillen, K. J., Ladd, J. W., and Worzel, J. L., 1979. Seismic evidence for widespread possible gas hydrate horizons on continental slopes and rises. Am. Assoc. Pet. Geol. Bull., 63:2204-2213.

Smith, M. B., and Forristal, G. Z., 1973. Triaxial compression tests, Leg 20, DSDP. In Heezen, B. C., MacGregor, I. D., et al., Init. Repts. DSDP, 20: Washington (U.S. Govt. Printing Office), 417-421.

von Huene, R., Aubouin, J., Azéma, J., Blackington, G., Carter, J., Coulbourn, W., Cowan, D., Curiale, J., Dengo, C., Faas, R., Harrison, W., Hesse, R., Hussong, D., Ladd, J., Muzylöv, N., Shiki, T., Thompson, P., and Westberg, J., 1980. The IPOD MidAmerica Trench transect off Guatemala. Bull. Geol. Soc. Am., Pt. I, 91:421-432.

von Huene, R., Nasu, N., Arthur, M., Cadet, J., Carson, R., Moore, G., Honza, E., Fujioka, K., Barron, J., Keller, G., Reynolds, R., Shaffer, B., Sato, S., and Bell, G., 1978. Japan Trench transected on Leg 57. Geotimes, 23:16-21.

\section{APPENDIX \\ Criteria for Distinguishing between Drilling- and Tectonic-Induced Deformation \\ (compiled by Shipboard Scientific Party, 1979)}

Drilling produces stresses that result in deformation of the core material. Downward force from drilling produces compression parallel to the core axis; rotation of the bit produces radial stresses symmetrical about the core center. Despite a bearing designed to isolate the core barrel from rotation, there commonly appears to be an undetermined amount of radial stress applied to the core as it enters the inner core barrel. When the material being cored is plastic, it deforms by macroscopic flow; when the material is brittle, it deforms by fracture, and associated zones of sheared material can become mobile and flow plastically. The overprint of drilling-induced deformation on original deformation is often difficult to isolate. Commonly the approach on board the Challenger is to identify obvious and suspected drill disturbance and attribute the remaining deformation to natural causes. Generally, there is certain amount of subjective judgment in ascribing an origin to deformation that falls between obvious drilling-induced deformation and obvious natural deformation.

Drilling-induced deformation generally is recognized from an orientation of features that is symmetrical to the core. Symmetrical plastic deformational features induced by drilling include the following:

1) A zone of flowage along and subparallel to the core liner.

2) Bending or hooking of horizontal beds in the direction of core penetration with tails along the core liner. 
3) Tight swirls that contrast with the general lesser intensity of core deformation, sometimes encountered when seas are rough enough to give the drill string a pumping action. These swirls have axes that trend in a circular pattern.

4) Sections of disturbed material are softer and contain more water than the rest of the core, at times containing randomly oriented drill cuttings. Such sections sometimes grade into obvious drill slurry.

Symmetry diagnostic of drilling-induced fracture occurs as sediment lithifies. The following are some commonly observed types of drilling-induced fractures (see Fig. 1):

1) Horizontal disk fractures that sometimes develop circular striations on polished surfaces. Such fractures develop as lithification of the cored material increases but the material is still readily cut with a wire. These fractures divide the core into short (about $5 \mathrm{~cm}$ ) segments and result in the biscuit structure. Biscuits are generally of uniform length separated by disturbed or sheared material up to $1 \mathrm{~cm}$ thick marking the horizontal disk fractures. Toward the core liner, these fractures and their associated gouge zones hook both up and down core.

2) Fractures originating near the core center, specially those with a radial symmetry in the down-core direction.

3) Vertical centerline fractures that become more obvious as the core dries.

Natural fracture generally lacks any form of rotational symmetry or a symmetry consistently related to the core axis. The following are features diagnostic of natural fracture:

1) Fractures with polished and slickensided faces and without radial symmetry.

2) Healed fractures, specially those filled with secondary minerals.

3) Fractures that extend across the core with no obvious relation to the core liner, esspecially fractures with high inclination. These are commonly observed in conjugate sets.

Natural fractures that are open in the laboratory may not necessarily be open fractures in situ. Fractures would be expected to open as core is cut, as lithostatic pressure is released, and as core is handled. Thus incipient fractures in situ may appear as open fractures in the core. In situ open fracturing is difficult to establish and can be inferred from detection of fracture porosity or from washouts shown by the caliper log in zones where fractured core has been recovered.

The most certain evidence of fracturing comes from healed fractures. When a core contains parallel healed and open fractures of the same character, the open fractures are likely to be opened original fractures. Thin-section examination of fractures can indicate reorientation of mineral grains or deposition of secondary minerals.

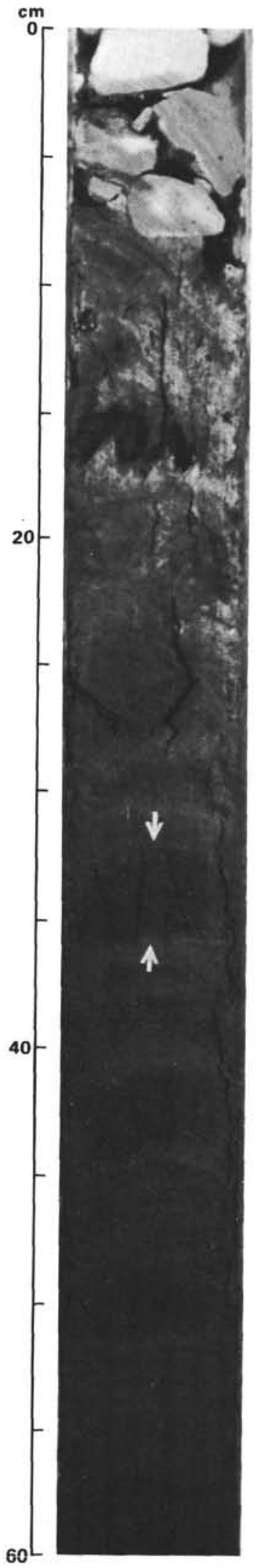

Figure 1. Section 494A-17-1 showing typical drilling-induced deformation features. (The arrows bound a drilling biscuit within which are axially symmetric fractures. Remolding of sediment between the biscuits as well as along the core liner edges is visible.) 